\title{
Correlation of Three Salinity Tolerance Screening Methods for Cool-season Turfgrasses
}

\author{
Matthew J. Koch ${ }^{1}$ and Stacy A. Bonos \\ Department of Plant Biology and Pathology, Rutgers The State University of \\ New Jersey, 59 Dudley Road, New Brunswick, NJ 08901
}

Additional index words. overhead irrigation, hydroponic, ryegrass

\begin{abstract}
The identification of turfgrasses with salinity tolerance will be important for the successful implementation of saline irrigation water use on turfgrass sites. Salinity tolerance in turfgrasses has been evaluated using different techniques, including hydroponic and overhead irrigation methods. This study compared turfgrass response and efficiency of three different salinity screening methods: hydroponic, an overhead irrigation greenhouse method, and a field screening method. There was a significant correlation among all three methods for percent green ratings and a significant correlation between the two greenhouse techniques for dry clipping weights, dry shoot weights, and dry root weights. A difference in magnitude was observed between methods. The overhead-irrigated greenhouse and field methods had lower percent green value ratings than the hydroponic method. However, similar rankings among perennial ryegrass clones were found between methods indicating that numerous methods can be used to screen turfgrass germplasm for salinity tolerance with similar results. The cost, time, and available area required and reliability varied depending on the method with the field screening requiring the most area $\left(929 \mathrm{~cm}^{2}\right.$ per plant) and cost (\$23.18 per plant) and the hydroponic method requiring the most time ( $48.3 \mathrm{~min}$ per plant). However, these results indicate any of these methods should be sufficient to screen germplasm for salinity tolerance. This information will be useful to plant breeding programs choosing selection methods for germplasm screening.
\end{abstract}

Breeding salinity tolerance into new turfgrass cultivars is of extreme importance as a result of increasing pressure from local governments to use wastewater as a replacement for potable irrigation water on turfgrass sites. This pressure typically occurs during times of extreme drought, when potable water needs to be conserved. Wastewater, including effluent water, may have increased salt levels (Duncan et al., 2000), which can cause salt stress injury, poor turf quality, and physiological drought on many currently available coolseason turfgrasses. Ice-melting salts (Marcum, 1994), salt spray, salt intrusion in groundwater (Newport, 1997; Todd, 1974), and flooding of the root zones on turfgrass sites planted near saltwater may also accumulate and cause increased electrical conductivity (EC) of soils. The turf quality of these areas would greatly increase from the use of salt-tolerant turfgrass cultivars. Additionally, if salt-tolerant turfgrass cultivars were used, it may expand the use of wastewater as irrigation and reduce maintenance costs of turfgrass areas forced to use low-quality irrigation water. Costs can also

\footnotetext{
Received for publication 2 Mar. 2011. Accepted for publication 6 June 2011.

We thank the United State Golf Association, the OJ Noer Research Foundation, the International Turf Producers Foundation, the New Jersey Turfgrass Foundation, and the Rutgers Center for Turfgrass Science for support for this project.

${ }^{1}$ To whom reprint requests should be addressed; e-mailmkoch@eden.rutgers.edu.
}

be further reduced because treated wastewater is typically less expensive than potable water (Cuthbert and Hajnosz, 1999).

Breeding turfgrasses for increased salinity tolerance requires an efficient screening method. First, the method must allow for the ability to quickly screen large numbers of plants. Second, cost and labor requirements must also be considered. Finally, the method must be highly reliable and repeatable. Many techniques for screening turfgrasses for salinity tolerance have been developed to identify germplasm that will be useful in breeding new cultivars with increased tolerance. One of the most popular methods for salinity screening is growing turfgrass plants in a hydroponic saline solution (Dai et al., 2009; Lee et al., 2004; Marcum, 2000; Marcum and Kopec, 1997; Marcum and Murdoch, 1994; Pessarakli and Kopec, 2008, 2009; Qian et al., 2000, 2001; Rose-Fricker and Wipff, 2001; SuplickPloense et al., 2002). However, with this method, only the roots are exposed to the saline solution and it does not include foliar applications of saline water. To address this issue, salinity screening methods using overhead irrigation were developed, in the field and greenhouse, to more accurately mimic the effects that turf managers would experience in field situations when using wastewater irrigation (Dai et al., 2008; Koch and Bonos, 2010; Walworth et al., 2009; Wu et al., 1999). However, it is not known whether data acquired from the use of overhead screening methods are correlated with more prevalently used methods.
The objectives of this study were to 1) correlate three different turfgrass salinity screening methods to effectively screen germplasm; and 2) compare the efficiency of each method for potential use in a breeding program.

\section{Materials and Methods}

Overhead-irrigated greenhouse method. The first method used an established overhead irrigation spray chamber system in the greenhouse (Koch and Bonos, 2010). In summary, the system included the use of recirculating salt spray chambers to apply overhead irrigation water to the plants. Eight individual clones from each of five perennial ryegrass cultivars, including Nui, Brightstar SLT, Paragon GLR, Applaud, and Palmer III, were taken from mature turfgrass plots at the Rutgers Plant Biology Research and Extension Farm in Freehold, NJ, for a total of 40 clones. The individual clones were separated into 12 replicates of equivalent size (approximately three to four tillers) planted into Promix growing media (Premier Tech Ltd., Quebec, Canada) and grown for 4 weeks in the greenhouse. Plants were then washed free of the growing media, roots were cut to $5.1 \mathrm{~cm}$, and shoots were cut to $3.8 \mathrm{~cm}$. One of the 12 replicate plants from each clone was randomly planted into a cell of a divided plastic tray containing Sureplay ${ }^{\circledR}$ topdressing sand from US Silica (Mauricetown, NJ). Each tray was considered a replicate. The plants were arranged in a randomized complete block design with three replications for each salinity treatment (described subsequently). Plants were irrigated with half-strength Hoagland's solution (Hoagland and Arnon, 1950) for 1 week to allow the plants to acclimate before treatments began. Instant Ocean aquarium salt (Spectrum Brands Inc., Atlanta, GA) was then added to the solutions at the rate of $1 \mathrm{dS} \cdot \mathrm{m}^{-1}$ each day until the final concentrations were achieved. The salinity treatments were as follows: Treatment 1 (control): $1 \mathrm{dS} \cdot \mathrm{m}^{-1}$, Treatment 2: $5 \mathrm{dS} \cdot \mathrm{m}^{-1}$, Treatment 3: $10 \mathrm{dS} \cdot \mathrm{m}^{-1}$, and Treatment 4: $15 \mathrm{dS} \cdot \mathrm{m}^{-1}$. All four solutions contained half-strength Hoagland's Solution, so the $\mathrm{EC}$ of the control solution did not equal zero. $\mathrm{EC}$ and $\mathrm{pH}$ of each treatment were measured and adjusted on each irrigation day. Irrigation with salt solutions continued every other day for 10 weeks. The first run of the experiment was performed in the spring of 2006 and the second in the fall of 2006.

Plant measurements included visual percent green ratings taken weekly, clipping yields taken biweekly, and shoot and root weights, which were taken at the conclusion of the 10week study. Visual percent green ratings were a measure of the percentage of each plant that remained green despite the salinity stress. Clipping yields were measured by removing shoot growth above the 3.8 -cm cutting height, drying the clippings for $48 \mathrm{~h}$ at $65{ }^{\circ} \mathrm{C}$, and weighing them. Finally, plants were removed from the trays, washed free of sand, and separated at the crown. Shoot weights were calculated by drying and weighing the crowns, shoots, and remaining leaf tissue, whereas 
root weights were measured by drying and weighing only the root tissue. Also at the conclusion of the study, representative soil samples were taken from each tray and soil EC was determined by the Rutgers Soil Testing Laboratory (New Brunswick, NJ) using the 1:2 soil:water extract method (Dellavalle, 1992).

The experiment was performed in a greenhouse with $400-\mathrm{W}$ high-pressure sodium supplemental lighting (Kavita Canada Inc., Niagara-on-the-Lake, Ontario, Canada) that provided photosynthetic active radiation in the range of 90 to $110 \mu \mathrm{mol} \cdot \mathrm{m}^{-2} \cdot \mathrm{s}^{-1}$ as measured with an Apogee Quantum Meter (Apogee Instruments Inc., Logan, UT). Daylengths were maintained at $14 \mathrm{~h}$ for both runs of the study. Greenhouse temperatures were set between 17 and $24^{\circ} \mathrm{C}$ (average temperature $=17.5^{\circ} \mathrm{C}$; $\mathrm{SD}=0.74)$ and were monitored with an Onset HOBO Pro Series data logging temperature probe (Bourne, MA). Greenhouse fans provided four air exchanges per minute. Humidity was not controlled during the course of the experiment.

Hydroponic greenhouse method. The second salinity screening technique evaluated was a greenhouse hydroponic method. This method followed previous hydroponic studies that have been published in the literature (Dai et al., 2009; Lee et al., 2004; Marcum, 2000; Marcum and Kopec, 1997; Marcum and Murdoch, 1994; Pessarakli and Kopec, 2008, 2009; Qian et al., 2000, 2001; RoseFricker and Wipff, 2001; Suplick-Ploense et al., 2002) with some modifications. A total of four salt-tolerant perennial ryegrass clones (three from Palmer III and one from Applaud) and four salt-sensitive clones (three from Brightstar SLT and one from Paragon GLR) (for a total of eight clones) were chosen for this experiment based on their salinity tolerance in a previous study (Koch and Bonos, 2010). These eight clones were a subset of the 40 clones that were included in the first screening method. Plant preparation, before the start of salinity treatments, was the same as described for the previous technique. After the roots and shoots were cut to size (5.1 and $3.8 \mathrm{~cm}$, respectively), plants were inserted into a sponge, which was then randomly inserted into a hole in a foam board (Dow Chemical Co., Midland, MI). Three replications of the eight individual clones were inserted into each of four foam boards, one for each salinity treatment.

The boards containing the plants were then placed on top of 30-cm-tall opaque plastic tanks (US Plastics, Lima, OH) containing halfstrength Hoagland's solution (Hoagland and Arnon, 1950) for 1 week. The same four salt treatments as described for the previous method were used: Treatment 1 (control): $1 \mathrm{dS} \cdot \mathrm{m}^{-1}$, Treatment 2: $5 \mathrm{dS} \cdot \mathrm{m}^{-1}$, Treatment 3: $10 \mathrm{dS} \cdot \mathrm{m}^{-1}$, and Treatment 4: $15 \mathrm{dS} \cdot \mathrm{m}^{-1}$. The solutions were changed weekly to prevent nutrients from becoming depleted. The salinity and $\mathrm{pH}$ were also checked and adjusted daily by adding or diluting salt solutions and adding acid $\left(\mathrm{H}_{2} \mathrm{SO}_{4}\right)$ or base $(\mathrm{NaOH})$ to maintain a $\mathrm{pH}$ equal to 6.5 (Murphy and Mohr, 2002). The study was conducted for 10 weeks and the entire exper- iment was repeated twice in the same greenhouse using the same settings as the other greenhouse method. The first run was performed in the spring of 2008, whereas the second was performed in the spring of 2009. The same measurements were collected as described previously: percent green ratings, clipping weights, shoot weights, and root weights.

Overhead-irrigated field method. The third screening method evaluated in this study was performed under field conditions at the Rutgers Plant Biology and Pathology Research and Extension Farm in Freehold, NJ. Similar to the first method, the same 40 perennial ryegrass clones [eight clones of each of five cultivars (Nui, Brightstar SLT, Paragon GLR, Applaud, Palmer III)] were used in this field experiment. The clones were separated into three replicates and established in the greenhouse for 4 weeks. The plants were planted into the field (Freehold sandy loam soil with $2.1 \%$ organic matter) on $30.5-\mathrm{cm}$ spacing and allowed to establish for an additional 4 weeks in the field before treatments began. Fertilizer was applied to the clones (98 kg nitrogen/ha) at planting and fresh water irrigation was applied as necessary during establishment. Perennial ryegrass clones were mowed weekly at $5 \mathrm{~cm}$. After establishment, plants were irrigated three times each week with a saline solution made from equal parts of $\mathrm{NaCl}$ and $\mathrm{CaCl}_{2}$. The concentration of the solution was equal to $10 \mathrm{dS} \cdot \mathrm{m}^{-1}$ and was made in an 1893-L tank with a gasoline-powered pump attached (Hights Farm Equipment Co., Monroe Twp., NJ). Using a digital flow meter (Mcmaster Carr, Elmhurst, IL) attached to a hose from the pump, $0.5 \mathrm{~L}$ of the salt solution from the tank was applied over the top of each plant. A total of 35 applications was applied onto the plants for each of the 2 years of this study. Weekly soil samples were taken and analyzed by the Rutgers Soil Testing Laboratory (New Brunswick, NJ) using the same method as the first technique. The first run of this study was performed in the summer of 2008 and the second in the summer of 2010. Four times per year, visual percent green ratings were taken on each individual beginning when salt stress appeared and differences were observed between clones.

Statistical analysis. Percent green ratings were subjected to analysis of variance (ANOVA) using PROC ANOVA (fixed-effect model) in SAS Version 9.1 (SAS Institute, 1991). Correlation analysis among the three methods was run on data from the highest salinity levels for each of the methods $\left(\mathrm{EC}=15 \mathrm{dS} \cdot \mathrm{m}^{-1}\right.$ for overhead-irrigated greenhouse and hydroponic methods and $\mathrm{EC}=10 \mathrm{dS} \cdot \mathrm{m}^{-1}$ for the overhead-irrigated field method) using PROC CORR in SAS Version 9.1 (SAS Institute, 1991). Only the final rating date was used for the correlation analysis because the field technique did not have weekly data. The highest salinity level and final rating date were also chosen because these conditions resulted in the largest differences in salinity tolerance between the perennial ryegrass clones. Correlation analysis for percent green ratings was analyzed on the eight common clones among all three methods and the 40 common clones between the overhead-irrigated greenhouse and field methods using PROC CORR in SAS. A correlation analysis was also run for dried clipping weights, shoot weights, and root weights from the first two methods. An estimation of the efficiency of the methods was estimated on a per-plant basis including all of the inputs required to conduct the screening procedures including area, costs, and time. Area requirement estimates included spacing between plants in the field and the greenhouse as well as the area required for irrigation equipment (i.e., spray chambers). Monetary costs were calculated based on the price of all materials required to perform the studies, including spray chambers, pump tanks, hydroponic tanks, space rental fees, and salts. The price of labor, however, was not included in this calculation but could be determined by multiplying the time required per plant by the hourly labor wage. Time inputs were measured to include system construction, plant preparation, plant maintenance, irrigation, and data collection.

\section{Results and Discussion}

Correlation of three salinity screening methods. Based on the ANOVA, method and clone were significant sources of variation (Table 1). These results indicated that there were significant differences between methods. The main difference was observed between the hydroponic method compared with the other two methods (Fig. 1) with the hydroponic method having significantly higher percent green ratings than the overhead-irrigated greenhouse and field methods. The two overhead screening methods were not significantly different from each other (Fig. 1). The hydroponic method may have had higher percent green ratings (i.e., less stress) because the salt solutions were not applied to the foliage compared with the other two methods, which resulted in more damage and lower percent green ratings most likely from foliar exposure to high EC irrigation water. Harivandi (2004) stated that irrigation water with increased salts may cause serious turf damage when applied overhead because sodium can be absorbed directly through foliar tissue and cause

Table 1. Analysis of variance of percent green values for three turfgrass salinity screening methods. $^{\mathrm{z}}$

\begin{tabular}{lc}
\hline & $\begin{array}{c}\text { Percent green } \\
\text { ratings }(P \text { values })\end{array}$ \\
\hline Year & NS \\
Rep & NS \\
Method & $* * *$ \\
Method $\times$ year & NS \\
Clone & $* * *$ \\
Clone $\times$ year & NS \\
Method $\times$ clone & NS \\
Method $\times$ clone $\times$ year & NS \\
\hline
\end{tabular}

${ }^{\text {z}}$ Salinity treatments for each method used in the correlation were: electrical conductivity (EC) = $15 \mathrm{dS} \cdot \mathrm{m}^{-1}$ for overhead-irrigated greenhouse and hydroponic methods and $\mathrm{EC}=10 \mathrm{dS} \cdot \mathrm{m}^{-1}$ for the overhead-irrigated field method.

NS $=$ non-significant.

***Significant at the $0.001 P$ level. 
toxicity. Other research has indicated stress associated with foliar applications of irrigation water with increased salinity in other crop species (including alfalfa and citrus) (Westcot and Ayers, 1984). Despite the magnitude of differences between the methods, all techniques proved to be effective in significantly discriminating between perennial ryegrass clones (Table 1) and the eight perennial ryegrass clones exhibited similar salinity tolerance in each of the three methods as indicated by the lack of a clone $\times$ method interaction (Table 1 ). Nelson (2008) also found that there was a significant correlation between results from greenhouse studies compared with field studies with respect to salinity tolerance of turfgrasses. These results indicate that any of these three methods can be used to screen turfgrasses for salinity tolerance and results should be similar regardless of the method chosen. This is important because it indicates that multiple methods can be used by different breeding programs to screen turfgrasses for salinity tolerance with similar results. This could hasten cultivar development.

The highest correlation for percent green ratings was observed between the two overhead-irrigated methods (greenhouse and field) with a correlation coefficient of $0.93(P=$ 0.0009 ) most likely because both techniques included overhead irrigation resulting in foliar stress. The overhead-irrigated field technique compared with the hydroponic method resulted in the next highest correlation coefficient of $0.82(P=0.0128)$. The overhead field method had a higher percent green value (more moderate) than the overhead-irrigated greenhouse technique albeit not significant (Fig. 1). This could be the result of the lower concentration of the irrigation water used in the field method $\left(\mathrm{EC}=10 \mathrm{dS} \cdot \mathrm{m}^{-1}\right)$, which may have been less stressful to the plants than using a higher concentration. The buffering capacity of soil or other soil-related effects may also have created a less stressful condition. The coefficient of 0.82 for this correlation is higher than expected because the field method included other environmental stresses such as heat, which can influence salinity stress. This is remarkable considering the fact that many other traits evaluated under greenhouse conditions, including disease evaluations, have not been found to be highly correlated to field performance (Bonos et al., 2006). These results are important for breeding programs because it indicates that germplasm can be screened in the greenhouse with similar anticipated field performance, which could save time, space, and resources.

The least correlated methods were the overhead-irrigated greenhouse method and the hydroponic method with a correlation coefficient of $0.72(P=0.0436)$. Although still significantly correlated, these two methods had the largest difference in percent green ratings (Fig. 1), which was most likely the result of differences in how saline solutions were applied, as stated previously. Wu et al. (1999) also found that saltwater applications applied overhead appear to be more damaging to plants when compared with irrigation of only the roots with saltwater of the same concentration.
Only eight perennial ryegrass clones were available to correlate across all three methods; however, another correlation analysis was conducted with the 40 perennial ryegrass clones in common between the overhead-irrigated greenhouse method and the overhead-irrigated field method. The correlation was very similar $\left(r^{2}=\right.$ $0.90 ; P=0.0131)$ indicating the values obtained with the eight clones were close to what might be expected if more plants were used for the correlation analysis.

A correlation analysis was also run on dried clipping weights, shoot weights, and root weights for the overhead-irrigated greenhouse and the hydroponic methods. The two methods were significantly correlated for clipping weights $\left(r^{2}=0.76 ; P=0.0281\right)$, shoot weights $\left(r^{2}=0.70 ; P=0.0469\right)$, and root weights $\left(r^{2}=0.79 ; P=0.0302\right)$. The significant correlation between the overhead-irrigated greenhouse technique and the hydroponic method for clipping, shoot, and root weights indicates that these methods may be used interchangeably to screen turfgrasses for salinity tolerance with consistency.

Efficiency of the overhead-irrigated greenhouse method. Space, time, and cost were the main factors for determining the efficiency of each salinity screening method (Table 2 ). The overhead-irrigated greenhouse method required $104.5 \mathrm{~cm}^{2}$ per plant. Plants could be planted close together because plants were separated by plastic dividers within each of the sand-filled trays. In fact, the only real limitation for space with this method would be the size of the greenhouse. Initial costs were

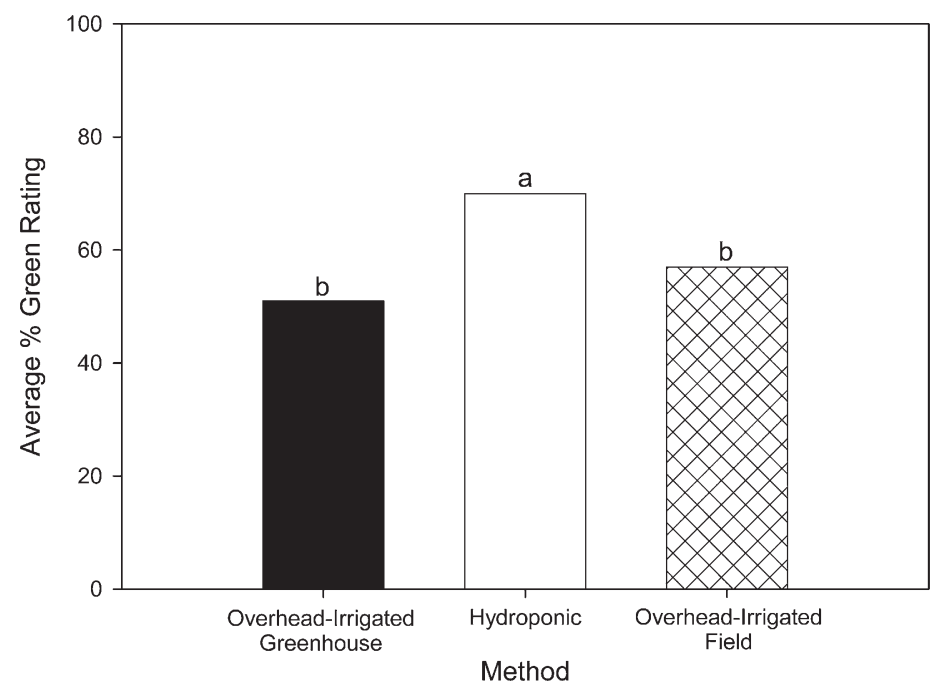

Fig. 1. Mean percent green values of three turfgrass salinity screening methods. Salinity treatments for each method used in the correlation were: $\mathrm{EC}=15 \mathrm{dS} \cdot \mathrm{m}^{-1}$ for overhead-irrigated greenhouse and hydroponic methods, and $\mathrm{EC}=10 \mathrm{dS} \cdot \mathrm{m}^{-1}$ for the overhead-irrigated field method. Letters indicate significant differences at the 0.05 level.

Table 2. Efficiency estimates of three turfgrass salinity screening methods based on area requirement, cost, time, and reliability. ${ }^{2}$

\begin{tabular}{lcccc}
\hline Method & Area/plant & Price/plant & Time/plant & $\begin{array}{c}\text { Reliability } \\
\text { and precision }\end{array}$ \\
\hline Overhead-irrigated greenhouse & $104.5 \mathrm{~cm}^{2}$ & $\$ 18.28$ & $14.63 \mathrm{~min}$ & High \\
Hydroponic greenhouse & $104.5 \mathrm{~cm}^{2}$ & $\$ 9.43$ & $48.26 \mathrm{~min}$ & High \\
Overhead-irrigated field & $929 \mathrm{~cm}^{2}$ & $\$ 23.18$ & $20.11 \mathrm{~min}$ & Low \\
\hline
\end{tabular}

${ }^{2}$ These estimates are calculated based on inputs to perform this correlation study. 
of the greenhouse (Table 2). Contrary to the other greenhouse method, the hydroponic technique does not require expensive initial construction costs, which made it the least expensive (of the three methods) costing only $\$ 9.43$ per plant (Table 2). However, monitoring and adjusting the $\mathrm{pH}$ and salinity levels required a significant time commitment. Additionally, the solutions needed to be changed weekly with this technique. Therefore, this method required the most time (of the three methods) at 48.26 min per plant (Table 2). This time requirement could be greatly reduced with the addition of automated nutrition and $\mathrm{pH}$ control; however, this is an extremely expensive addition. If this is the chosen method to screen turfgrasses for salinity tolerance, investing in automated control of these factors may be beneficial to prevent the time requirements from becoming restrictive. The reliability and precision of this method is very high, like the other greenhouse technique, because the study is performed in the greenhouse, the environment is controlled, and plants are easily accessible for additional measurements (Table 2).

Efficiency of the overhead-irrigated field method. The area requirement for this technique is the largest of all the methods $\left(929 \mathrm{~cm}^{2}\right.$ per plant) because the plants are not confined to a limited space and need to be separated by space to prevent plants from growing together (Table 2). However, field space tends to be less limiting than greenhouse space so the opportunity exists to screen the largest number of plants compared with the other two methods. This method was the most expensive on a per-plant basis because of the initial cost of purchasing the pump tank at $\approx \$ 5000$. Additionally, salt solutions are not recirculated with this method so the salts needed to be replenished. This brought the cost to $\approx \$ 23.18$ per plant. Like with the overhead-irrigated greenhouse method, costs could be reduced with further screening of germplasm. To date, the authors have evaluated more than 30,000 plants with this method, which reduced the cost down to $\$ 0.45$ per plant. The time requirement for this method was in between the other two methods; however, if adequate weed control is not available, the time may be increased. This method is subject to changing environmental conditions such as rain events, which could prolong the time it would take for stress to become evident. For example, large amounts of rain can leach the salts from the soil and decrease the soil EC. This occurred in the summer of 2009 when the trial received large quantities of rain with each rain event, resulting in a lack of observable salinity stress. For example, in Sept. 2008, soil salinity was reduced from 2.98 to 1.80 after a $4.5-\mathrm{cm}$ rain event. Salt solution applications were continued after rain events to prevent plant recovery. The growing seasons of 2008 and 2010 had total rainfall of 43.1 and $32.5 \mathrm{~cm}$, respectively. However, despite rain events, periods without rainfall did occur and high levels of soil salinity were achieved by the end of both runs of the field study (Run $1=2.89 \mathrm{dS} \cdot \mathrm{m}^{-1}$; Run $2=2.95$ $\left.\mathrm{dS} \cdot \mathrm{m}^{-1}\right)$. This soil salinity concentration is at a level that would cause salt stress and damage to most cool-season turf species (Carrow and
Duncan, 1998). Because this technique is carried out in the field, the reliability and therefore consistency is lower than the other two methods (Table 2). Although this method most simulates the true turfgrass environment, which includes other environmental stresses (i.e., heat, drought, etc.), it was still highly correlated to the greenhouse techniques, which did not include these stresses indicating the greenhouse screening may be used to predict mature turfgrass field performance.

\section{Conclusions}

All three of the described techniques were significantly correlated to one another and effective in differentiating between perennial ryegrass clones for salinity tolerance. The hydroponic method did not cause as much stress as the overhead-irrigated greenhouse or field methods, which may be attributable to the lack of foliar stress with the hydroponic method. The overhead-irrigated and hydroponic greenhouse methods both required similar amounts of space to conduct the experiment, whereas the field method required a much larger area. As a result of initial costs, the overheadirrigated greenhouse and field methods had higher per-plant costs, but with further screening of germplasm, these costs could be reduced. The reliability of the field method was lower than the two greenhouse methods because of changing environmental conditions in the field; however, the field method was designed to most accurately mimic a true turfgrass-growing environment. All three of the methods described were useful for screening tufgrasses for salinity tolerance. The chosen method will depend on the time, cost, area available, and the amount or type of data collected. As a result of the high correlation between techniques, it can be assumed that whichever method is chosen, it should produce similar results when compared with other salinity screening methods being performed by other researchers. This knowledge could be used to help coordinate breeding efforts in different locations and may result in faster cultivar development.

\section{Literature Cited}

Bonos, S.A., B.B. Clarke, and W.A. Meyer. 2006. Breeding for disease resistance in the major cool-season turfgrasses. Annu. Rev. Phytopathol. 44:213-234.

Carrow, R.N. and R.R. Duncan. 1998. Salt affected turfgrass sites: Assessment and management. Ann Arbor Press, Chelsea, MI.

Cuthbert, R.W. and A.M. Hajnosz. 1999. Setting reclaimed water rates. J. Amer. Water Works Assoc. 91:50-57.

Dai, J., D.R. Huff, and M.J. Schlossberg. 2009. Salinity effects on seed germination and vegetative growth of greens-type Poa annua relative to other cool-season turfgrass species. Crop Sci. 49:696-703.

Dai, J., M.J. Schlossberg, and D.R. Huff. 2008 Salinity tolerance of 33 greens-type Poa апnиа experimental lines. Crop Sci. 48:1187-1192.

Dellavalle, N.B. 1992. Determination of specific conductance in supernatant 1:2 soil:water solution, p. 44-50. In: Handbook on reference methods for soil analysis. Soil and Plant Analysis Council, Athens, GA.
Duncan, R.R., R.N. Carrow, and M. Huck. 2000. Effective use of seawater irrigation on turfgrass. USGA Green Section Record Jan/Feb:11-17.

Harivandi, M.A. 2004. Evaluating recycled waters for golf course irrigation. USGA Green Section Record Nov/Dec:25-29.

Hoagland, D.R. and D.I. Arnon. 1950. The waterculture method for growing plants without soil. California Agr. Exp. Stn. Circular 347.

Koch, M.J. and S.A. Bonos. 2010. An overhead irrigation screening technique for salinity tolerance in cool-season turfgrasses. Crop Sci. 50:2613-2619.

Lee, G., R.N. Carrow, and R.R. Duncan. 2004. Photosynthetic responses to salinity stress of halophytic seashore paspalum ecotypes. Plant Sci. 166:1417-1425.

Marcum, K.B., 1994. Salt-tolerance mechanisms of turfgrasses. Golf Course Management Sept:55-59.

Marcum, K.B. 2000. Salt tolerance varies in modern creeping bentgrass varieties. Golf Course Management Oct:54-58.

Marcum, K.B. and D.M. Kopec. 1997. Salinity tolerance of turfgrasses and alternative species in the subfamily chloridoideae (poaceae). ITS Reasearch Journal. 8:735-742.

Marcum, K.B. and C.L. Murdoch. 1994. Salinity tolerance mechanisms of six $\mathrm{C} 4$ turfgrasses. J. Amer. Soc. Hort. Sci. 119:779-784.

Murphy, J.A. and M. Mohr. 2002. Perennial ryegrass varieties for New Jersey. Rutgers Cooperative Research \& Extension, NJAES, Rutgers, The State University of New Jersey, New Brunswick, NJ.

Nelson, L.R. 2008. Breeding turf-type annual ryegrass for salinity tolerance. 2008 USGA Turfgrass and Environmental Research Summary. p. 50.

Newport, B.P. 1997. Saltwater intrusion in the United States. EPA-600/8-77-011.

Pessarakli, M. and D.M. Kopec. 2008. Establishment of three warm-season grasses under salinity stress. Acta HortScience, ISHS. 783:29-37.

Pessarakli, M. and D.M. Kopec. 2009. Screening various ryegrass cultivars for salt stress tolerance. J. Food Agr. Environ. 7:739-743.

Qian, Y.L., M.C. Engelke, and M.J.V. Foster 2000. Salinity effect on zoysiagrass cultivars and experimental lines. Crop Sci. 40:488-492.

Qian, Y.L., S.J. Wilhelm, and K.B. Marcum. 2001. Comparative response of two kentucky bluegrass cultivars to salinity stress. Crop Sci. 41:1895-1900.

Rose-Fricker, C. and J.K. Wipff. 2001. Breeding for salt tolerance in cool-season turfgrasses. ITS Research Journal. 9:206-212.

SAS Institute. 1991. SAS/STAT user's guide. SAS Inst., Cary, NC.

Suplick-Ploense, M.R., Y.L. Qian, and J.C. Read. 2002. Relative $\mathrm{NaCl}$ tolerance of Kentucky bluegrass, Texas bluegrass, and their hybrids. Crop Sci. 42:2025-2030.

Todd, D.K. 1974. Salt-water and its control. J. Amer. Water Works Assoc. 66:180-187.

Walworth, J., D. Kopec, A. Pond, and J. Gilbert. 2009. Turfgrass systems for saline irrigation water. Turfgrass, Landscape, and Urban IPM Research Summary Feb:47-56.

Westcot, D.W. and R.S. Ayers. 1984. Irrigation water quality criteria. In: Irrigation with reclaimed municipal wastewater: A guidance manual. California State Water Resource Control Board, Sacramento, CA.

Wu, L., X. Guo, A. Harivandi, R. Waters, and J. Brown. 1999. Study of California native grass and landscape plant species for recycled water irrigation in California landscapes and gardens. Report of the Elvinia J. Slosson fund for ornamental horticulture 1998-1999. University of California Division of Agriculture and Natural Resources, Oakland, California. 